\title{
Hubungan Imunoekspresi E-cadherin dan $C$-erbB2 dengan Derajat Keganasan Histopatologik Karsinoma Kistik Adenoid Kelenjar Liur
}

\author{
Marry Siti Mariam, Wazilah Nasserie \\ Jurusan Biologi Mulut Fakultas Kedokteran Gigi Universitas Padjadjaran
}

\begin{abstract}
Abstrak
Karsinoma kistik adenoid (KKA) merupakan keganasan kelenjar liur terbanyak, prognosisnya sukar diprediksi dengan tingkat kekambuhan yang tinggi. Berdasarkan beberapa penelitian, prognosis KKA kelenjar liur yang berhubungan dengan tingkat ketahanan hidup sangat terkait dengan derajat keganasan histopatologik berdasarkan tipe pola pertumbuhannya. Penelitian ini dilaksanakan di Departemen Patologi Anatomi Fakultas Kedokteran Universitas Padjadjaran Bandung tahun 2009. Tujuan penelitian untuk mengetahui perubahan imunoekspresi protein adhesi E-cadherin (molekul adhesi antar sel epitel) dan proto-onkogen C-erbB2 (keluarga C-erbB/reseptor faktor pertumbuhan epidermal) pada KKA kelenjar liur dikorelasikan dengan derajat keganasan histopatologik. Desain penelitian studi potong lintang tanpa acak secara retrospektif pada 51 blok parafin penderita karsinoma kistik adenoid kelenjar liur. Sampel didiagnosis ulang, serta ditentukan derajat keganasan histopatologiknya (menurut modifikasi Szantos dan Batsakis) dilanjutkan dengan pemeriksaan imunohistokimia terhadap E-cadherin dan $C$-erbB2. Hasil menunjukkan korelasi sangat bermakna $(\mathrm{p}<0,01)$ perubahan imunoekspresi E-cadherin yang negatif (82\%) dengan derajat keganasan histopatologik 1, 2, dan 3 (4\%, 33\%, dan 46\%). Perubahan imunoekspresi $C$-erbB2 tidak berkorelasi dengan meningkatnya derajat keganasan $(\mathrm{p}=0,11)$. Terjadi perubahan peningkatan imunoekspresi dari derajat $1(5 \%)$ ke derajat $2(11 \%)$, namun kembali menurun pada derajat $3(8 \%)$. Simpulan, imunoekspresi E-cadherin dapat digunakan sebagai petanda tumor untuk memprediksi prognosis keganasan KKA kelenjar liur. Perubahan imunoekspresi $C$-erbB2 pada KKA kelenjar liur menunjukkan perilaku biologinya dan peran utama $C$-erbB2 pada KKA kelenjar liur terutama pada fase inisiasi dan promosi karsinogenesis. [MKB. 2012;44(2):70-6].
\end{abstract}

Kata kunci: $C$-erbB2, derajat keganasan histopatologik, E-cadherin, karsinoma kistik adenoid kelenjar liur

\section{Correlation of E-cadherin and C-erbB2 Immunoexpression with the Degree of Histopathological Malignancy on Salivary Gland Adenoid Cystic Carcinoma}

\begin{abstract}
Adenoid cystic carcinoma (ACC) is the most common salivary gland malignancies, with high rate of local recurrence and unpredictable prognosis. Based on previous research, prognosis of ACC in salivary gland which is correlated with survival rates, is related with histopathological malignancy degree based on its growth pattern type. This study was conducted in Pathology Anatomy Department of Medical Faculty, Padjadjaran University Bandung in 2009. The aim of this study was to analyze the alteration of immunoexpression of E-cadherin (adhesion molecule of epithelial cells) and C-erbB2 proto-oncogen (the family of C-erbB/epidermal growth factor receptor) in salivary gland. Adenoid cystic carcinoma correlated with cross-sectional non-random study on 51 paraffin blocks, from patients with salivary gland ACC retrospectively. The repeated histopatologic examination was to diagnose ACC and to get data of the histopathological malignancy degree (according to Szantos and Batsakis modification), and it was continued with immunohistochemistry examination of E-cadherin and C-erbB2. The alteration of negative immunoexpression of E-cadherin $(82 \%)$ had correlation significantly $(p<0.001)$ with the histological malignancy degrees 1,2 , and $3(4 \%, 33 \%$ and $46 \%)$. The C-erbB2 immunoexpression change had no correlation with the increasing histopatologic malignancy degree $(\mathrm{p}=0.11)$. The alteration of $\mathrm{C}$-erbB2 immunoexpression, increased from first $(5 \%)$ to second degree $(11 \%)$ but decreased on the third degree $(8 \%)$. In conclusions, the immunoexpression of E-cadherin can be used as tumor marker to predict malignancy prognosis of salivary gland ACC. The expression changes of C-erbB2 in ACC indicate its biological behavior and the main role of C-erbB2 on salivary gland ACC is in the initiation and promotion phase of carcinogenesis. [MKB. 2012;44(2):70-6].
\end{abstract}

Key words: C-erbB2, E-cadherin, histopathological malignancy degree, salivary gland adenoid cystic carcinoma

Korespondensi: Dr. Marry Siti Mariam, drg., M.Kes, Jurusan Biologi Mulut Fakultas Kedokteran Gigi Universitas Padjadjaran, jalan Sekeloa Selatan 1 Bandung, telepon (022) 2504985, mobile 081905088875, e-mail marryibrahim@yahoo.com 


\section{Pendahuluan}

Karsinoma rongga mulut frekuensinya cenderung bertambah dan hingga kini di negara berkembang menempati urutan ke-6 dari 10 jenis kanker yang paling sering ditemukan dalam rongga mulut. ${ }^{1}$ Karsinoma kistik adenoid/KKA (adenoid cystic carsinoma) termasuk tumor ganas jenis epitel, $10-15 \%$ terdapat di kepala serta leher dan paling banyak terjadi pada kelenjar liur. Karsinoma kistik adenoid merupakan tumor ganas infiltratif, tumbuh lambat namun dapat menyebar dengan ganas ke jaringan sekitarnya, kemampuan metastasis jauh secara hematogen, dan sangat mudah kambuh. Pada kasus KKA dengan metastasis jauh, hanya $20 \%$ penderita yang dapat tertolong (dalam kurun waktu kurang dari 4 atau 5 tahun), 33\% kasus tersebut meninggal dalam kurun waktu kurang dari dua tahun walaupun telah dilakukan eksisi bedah yang luas dan dilakukan radioterapi. ${ }^{2}$ Karena sifat biologisnya yang agresif, penderita KKA kelenjar liur mempunyai prognosis yang buruk dalam waktu yang lama. ${ }^{1,3}$

E-cadherin merupakan molekul adhesi antar sel epitel. Mutasi gen pengontrol molekul adhesi akan menyebabkan penurunan kemampuan adhesi sel atau bahkan tidak ada adhesi sel. ${ }^{4}$ Selain itu, berkurangnya adhesi antar sel pada jaringan tumor dapat menyebabkan mudah terlepasnya sel tumor dari jaringan tumor primer, dan hal ini merupakan tahap awal invasi serta metastasis. ${ }^{5}$ Berdasarkan berbagai penelitian karsinoma kelenjar payudara, imunoekspresi $E$-cadherin telah ditetapkan sebagai petanda keganasan. ${ }^{6,7}$

Onkogen $C$-erbB2 diduga sebagai petanda prognostik pada beberapa tumor kelenjar liur. Laporan penelitian menyatakan bahwa gangguan fungsi $E$-cadherin dan $\beta$-catenin diduga dapat meningkatkan ekspresi $C$-erbB2 dan memengaruhi prognosis kanker sel skuamosa. ${ }^{8}$ Ekspresi protein $C$-erbB2 pada KKA menurut beberapa penelitian, baik korelasinya terhadap tipe pola pertumbuhan maupun persentasenya menunjukkan hasil yang sangat bervariasi mulai dari $0 \%, 16 \%, 50 \%$, sampai $100 \%{ }^{9}$ Penggunaan anti-C-erbB2 pada berbagai keganasan telah banyak diteliti dan juga penggunaan trastuzumab telah ditetapkan sebagai anti-C-erbB2 pada penderita kanker payudara yang memperlihatkan ekspresi berlebih $C$-erbB2.

Dalam perkembangan penelitian, menentukan derajat keganasan sering dipakai sebagai suatu indikator prognostik termasuk karsinoma mulut. Jaringan tumor KKA memperlihatkan gambaran histopatologis yang bervariasi dan terbagi atas tiga tipe pola pertumbuhan, yaitu tipe tubular (tubulodaktal), kribiform (glandular), dan solid. Tipe pola pertumbuhan solid merupakan tipe yang paling sering dihubungkan dengan prognosis yang buruk serta penyebab kematian, oleh karena itu peneliti sering menggolongkan derajat keganasan histopatologik berdasarkan terdapatnya tipe solid. ${ }^{10,11}$ Menurut hasil beberapa penelitian peran prognosis yang berhubungan dengan tingkat ketahanan hidup yaitu derajat keganasan histopatologik dan bukan berdasarkan tipenya. ${ }^{9-11}$

Tujuan penelitian untuk mengetahui keterkaitan ekspresi E-cadherin dan $C$-erB2 dengan derajat keganasan histopatologik pada KKA kelenjar liur serta gen petanda tersebut secara terpisah atau bersamaan sebagai faktor prognosis KKA kelenjar liur.

\section{Metode}

Bahan diperoleh dari jaringan hasil biopsi penderita karsinoma pada kepala dan leher dengan diagnosis KKA kelenjar liur yang telah direndam dalam blok parafin disertai rekam medis penderita dan sediaan hematoksilin-eosin (HE). Penelitian ini dirancang menggunakan studi potong lintang observasional secara tanpa acak (non-random) untuk mendapatkan model prediktif imunoekspresi $E$-cadherin dan $C$-erbB2 terhadap parameter derajat keganasan histopatologik KKA kelenjar liur.

Subjek penelitian yaitu jaringan tumor dengan diagnosis histopatologi KKA kelenjar liur pada 51 blok parafin dengan karsinoma adenoid kistik kelenjar liur secara retrospektif sejak tahun 1998 sampai awal 2006. Pada tahun 2009 semua sampel tumor didiagnosis kembali untuk menentukan diagnosis KKA dan juga untuk mendapatkan derajat keganasan secara histopatologik (modifikasi Szantos dan Batsakis) dengan pulasan $\mathrm{HE}$, kemudian dilanjutkan dengan pemeriksaan imunohistokimia terhadap E-cadherin dan C-erbB2.

Derajat keganasan histopatologik ditentukan berdasarkan pola pertumbuhan KKA kelenjar liur (tipe tubular, kribiform, dan solid). Kriteria penilaian merupakan modifikasi dari metode Szantos dkk. ${ }^{10}$ dan Batsakis dkk..$^{11}$ yaitu derajat 1 , campuran tipe tubular dengan kribiform tanpa tipe solid; derajat 2 tipe kribiform saja atau campuran dengan tipe solid $(<30 \%)$; dan derajat 3 merupakan tipe campuran dengan tipe solid $>30 \%$.

Imunoekspresi E-cadherin diukur berdasarkan intensitas pulasan imunohistokimia (negatif, lemah, sedang, dan kuat), berdasarkan kelompok distribusi pola pulasan imunohistokimia, yaitu 0 jika negatif, dan jika sel jaringan tumor KKA imunoreaktif +1 $(<25 \%),+2(\geq 25-50 \%),+3(>50-75 \%)$, dan +4 $(>75 \%)$. Penilaian imunoekspresi $C$-erbB2 negatif (jika tidak ada atau $<10 \%$ sel tumor terwarna positif) dan positif (apabila $\geq 10 \%$ sel tumor terwarna positif). 
Analisis bivariat untuk mengetahui hubungan/ besarnya risiko antara masing-masing variabel bebas (E-cadherin dan $C$-erbB2) dengan variabel terikat (derajat keganasan histopatologik berdasarkan tipe pola pertumbuhan KKA), sedangkan analisis multivariat dilakukan untuk uji secara simultan antara beberapa variabel bebas dan variabel terikat. Untuk analisis statistik disertakan jenis uji, nilai statistik, dan kemaknaan uji statistik berdasarkan nilai $\mathrm{p}<0,05$ (taraf kepercayaan 95\%).

\section{Hasil}

Persentase ekspresi E-cadherin dari 51 kasus jaringan KKA kelenjar liur mayoritas adalah negatif (82\%), sedangkan persentase ekspresi $C$-erbB2 negatif (sel tumor terwarna $<10 \%$ ) sedikit lebih

Tabel 1 Frekuensi Imunoekspresi E-cadherin, C-erbB, dan Korelasinya terhadap Derajat Keganasan Histopatologik KKA Kelenjar Liur

\begin{tabular}{ccccccc}
\hline \multirow{2}{*}{ Protein } & \multirow{2}{*}{ Ekspresi } & $\begin{array}{c}\text { Frekuensi } \\
(\mathbf{n}=\mathbf{5 1})\end{array}$ & \multicolumn{2}{c}{ Derajat Keganasan Histopatologik } & \multirow{2}{*}{ Kemaknaan } \\
\cline { 4 - 6 } E-cadherin & Negatif & $42(82 \%)$ & $2(4 \%)$ & $17(33 \%)$ & $23(45 \%)$ & Zm-w=3,364 \\
& $\begin{array}{c}\text { Positif Intensitas: } \\
\text { - Lemah }\end{array}$ & $9(18 \%)$ & $3(6 \%)$ & $6(12 \%)$ & - & $\mathrm{p}<0,001$ \\
& - Sedang & - & - & - & - & \\
& - Kuat & - & - & - & - & \\
& Distribusi: & & & & & \\
& +1 & 7 & 2 & 5 & - & $\mathrm{r}_{\mathrm{s}}=-0,4777$ \\
& +2 & 2 & 1 & 1 & - & $\mathrm{p}<0,001$ \\
& +3 & - & - & - & - & \\
C-erbB2 & Negatif & $27(53 \%)$ & - & $12(24 \%)$ & $15(29 \%)$ & $\mathrm{r}=2,131$ \\
& Positif & $24(47 \%)$ & $5(10 \%)$ & $11(21 \%)$ & $8(16 \%)$ & $\mathrm{p}<0,033$ \\
\hline
\end{tabular}

Keterangan: $\mathrm{r}_{\mathrm{s}_{\mathrm{Z}}}=$ koefisien korelasi rank Spearman

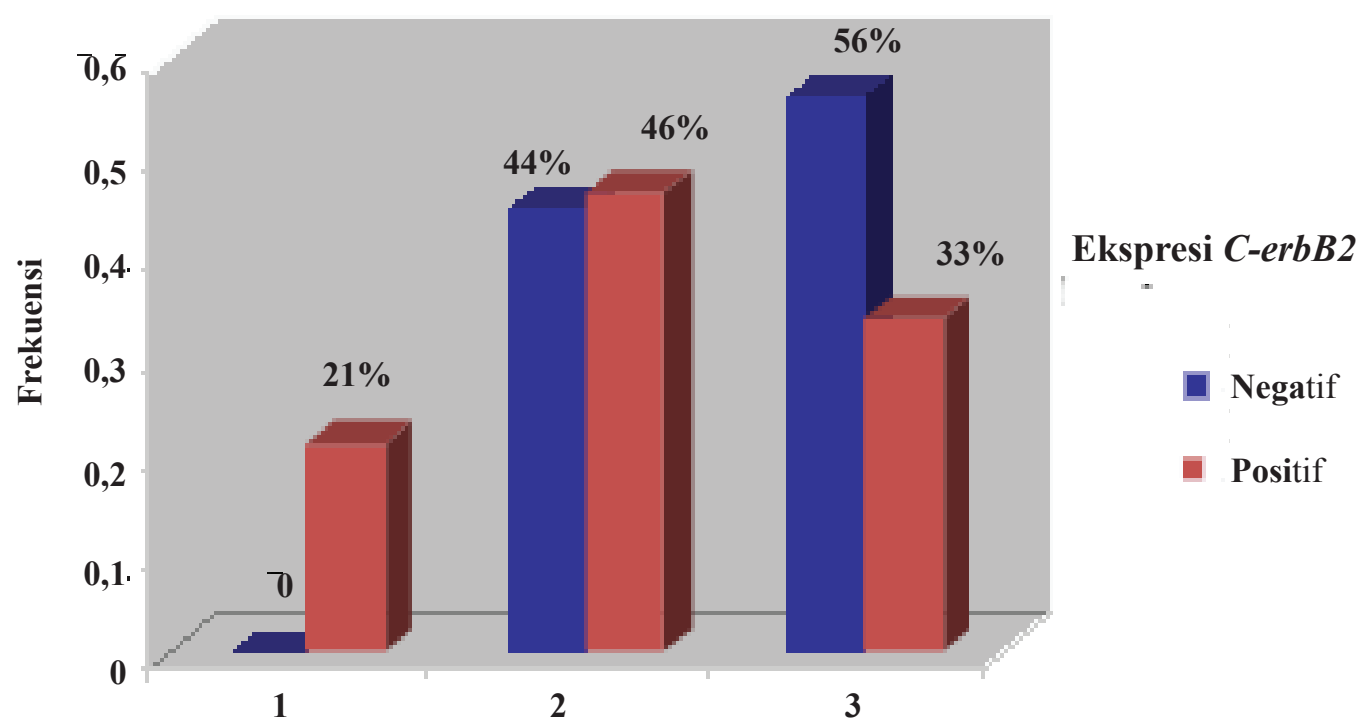

Derajat Keganasan Hispatologik

Gambar 1 Hubungan Ekspresi Positif dan Negatif C-erbB2 dengan Derajat Keganasan Histopatologik 


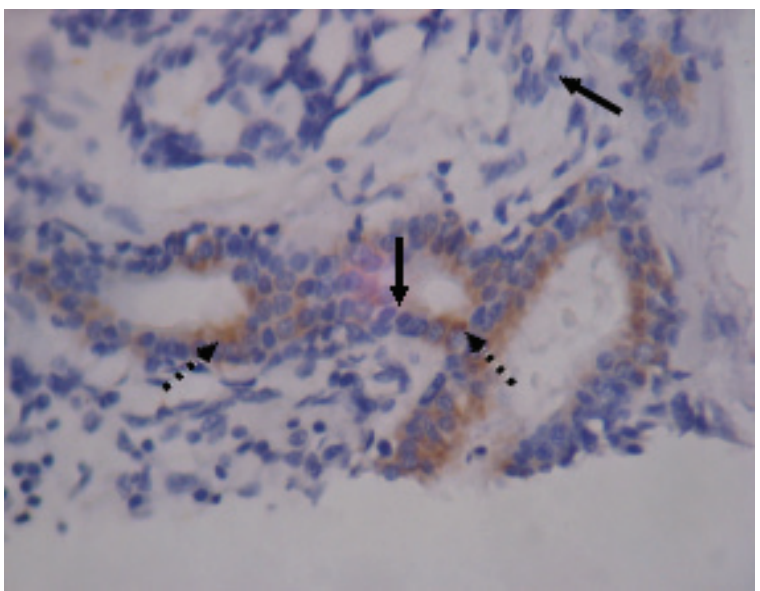

Gambar 2 Imunoekspresi E-cadherin, Pembesaran (400x). Pulasan Positif Intensitas Lemah (Panah Penuh), Pulasan Negatif (Panah Terputus)

banyak yaitu 53\% dibandingkan dengan yang positif (>10\%) yaitu 47\% (Tabel 1).

Digunakan uji Mann-Whitney $\left(\mathrm{Z}_{\mathrm{M}-\mathrm{W}}\right)$ dan koefisien korelasi rank Spearman $\left(\mathrm{r}_{\mathrm{S}}\right)$, hasilnya menunjukkan hubungan negatif antara ekspresi $E$-cadherin dan derajat keganasan histopatologik sangat bermakna. Ekspresi negatif E-cadherin mengarah ke derajat keganasan $3\left(\mathrm{Z}_{\mathrm{M}-\mathrm{W}}=3,364 ; \mathrm{p}\right.$ $<0,001)$, yaitu derajat 3 sebanyak 23 kasus $(55 \%)$, diikuti derajat 2 sebanyak 17 kasus $(40 \%)$, dan derajat 1 paling sedikit hanya 2 kasus (5\%) (Tabel $1)$.

Imunoekspresi $C$-erbB2 memiliki hubungan bermakna dengan derajat histopatologik (ZM$\mathrm{W}=2,131 ; \mathrm{p}=0,033)$. Hubungan ekspresi $C$-erbB2 dengan derajat keganasan histopatologik yang positif terbanyak pada derajat 2 (11 kasus) dan yang negatif terbanyak pada derajat 3 (15 kasus). Hal ini tampak jelas pada grafik batang $C$-erbB2 (Gambar 3). Tampak hubungan ekspresi positif dan negatif $C$-erbB2 dengan derajat keganasan histopatologik, terlihat $C$-erbB2 yang positif pada derajat 1 (5 kasus), meningkat pada derajat 2 (11 kasus), dan menurun pada derajat 3 (8 kasus), sedangkan yang negatif pada derajat 1 tidak ada dan terbanyak pada derajat 3 (15 kasus).

Derajat keganasan histopatologik 1 dan 2 digabungkan sehingga diperoleh dua kelompok derajat keganasan tinggi (derajat 3) dan derajat keganasan rendah $(1+2)$. Skoring menggabungkan intensitas dan distribusi pulasan $\mathrm{HE}$ bertujuan untuk menentukan kelompok ekspresi tinggi dan rendah. Skor gabungan E-cadherin (0 dan $\geq 1$ ), yaitu untuk intensitas negatif diberi skor 0 , sedangkan skor 1 jika intensitas lemah distribusi +1 , dan skor 2 jika intensitas lemah distribusi +2 . Tampak bahwa hubungan negatif antara

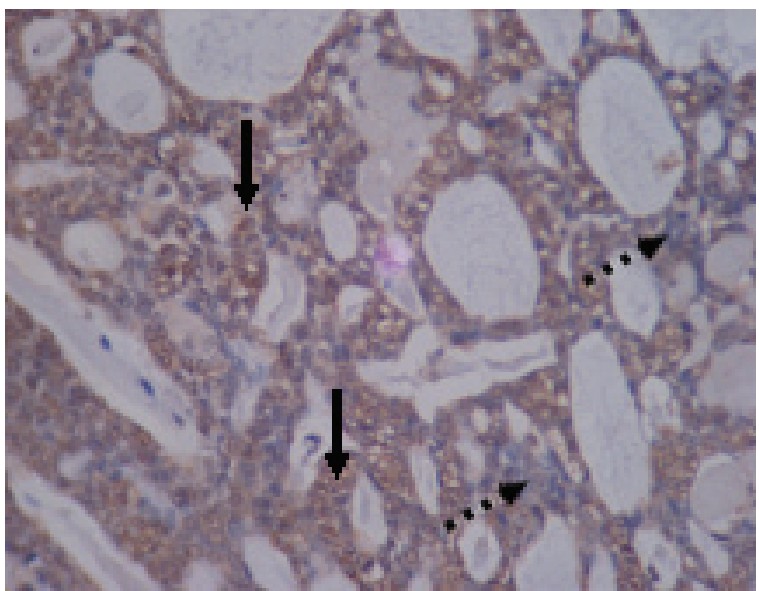

Gambar 3 Imunoekspresi $C$-erbB2, Pembesaran $(400 x)$. Imunoekspresi Negatif $C$-erbB2 (Panah Terputus), Positif (Panah Penuh)

ekspresi $E$-cadherin dan tingkat keganasan tinggi sangat bermakna $\left(X^{2}=8,977 ; p<0,011\right)$, namun hubungan antara ekspresi $C$-erbB2 dan tinggi/ rendahnya derajat keganasan, tidak bermakna $(\mathrm{p}=0,11)($ Tabel 2$)$.

\section{Pembahasan}

Pada penelitian ini tidak memungkinkan dilakukan analisis tingkat ketahanan hidup (survival rate) kasus KKA kelenjar liur, karena kelengkapan rekam medis penderita yang tidak memadai. Pada prinsipnya skala derajat keganasan histopatologik (1 sampai 3 ) berdasarkan persentase tipe solid diambil untuk menandakan buruknya prognosis KKA. Hal tersebut berdasarkan pernyataan dari seluruh acuan pustaka yang ada bahwa pola pertumbuhan tipe solid telah disepakati mempunyai prognosis yang sangat buruk pada KKA dengan tingkat kekambuhan hampir $100 \% .^{1,2}$

Usia penderita saat diagnosis, jenis kelamin, atau lokasi tumor (kelenjar liur mayor dan minor) yang merupakan variabel penyerta pada penelitian ini, tidak mempunyai pengaruh yang bermakna pada derajat keganasan histopatologik.

Prognosis KKA dapat ditentukan berdasarkan lokasi, ukuran anatomi, terdapatnya tumor di daerah tepi (marginal) operasi, dan tipe pola pertumbuhan secara histopatologis. Dalam perkembangannya, penentuan derajat keganasan sering dipakai sebagai suatu indikator prognostik termasuk pada karsinoma mulut. Menurut hasil beberapa penelitian pada KKA peran prognosis yang berhubungan dengan tingkat ketahanan hidup yaitu derajat keganasan histopatologik dan bukan berdasarkan tipenya. ${ }^{10,11}$

Beberapa peneliti menggunakan kriteria derajat 
Tabel 2 Hubungan Ekspresi E-cadherin dan C-erbB2 dengan Derajat Keganasan Histopatologik

\begin{tabular}{|c|c|c|c|c|}
\hline & & Derajat $\mathrm{Ke}$ & Histopatologik & \\
\hline & Variabel & $\underset{n}{\text { Tinggi (3) }}$ & $\underset{n}{\operatorname{Rendah}(1+2)}$ & Kemaknaan \\
\hline E-cadherin & Negatif & $23(45 \%)$ & $19(37 \%)$ & $\mathrm{pEF}=0,002$ \\
\hline & Positif Intensitas: & & & \\
\hline & Lemah & 0 & $9(18 \%)$ & \\
\hline & Sedang & - & - & \\
\hline & Kuat & - & - & \\
\hline & Distribusi: & & & \\
\hline & +1 & - & 7 & $X^{2}=8,977$ \\
\hline & +2 & - & 2 & $\mathrm{p}=0,011$ \\
\hline & +3 & - & - & \\
\hline & +4 & - & - & \\
\hline & Skor E-chaderin & & & \\
\hline & 0 & 23 & 19 & \\
\hline & $\geq 1$ & 0 & 9 & \\
\hline & Negatif & $15(29 \%)$ & $12(24 \%)$ & $X^{2}=2,534$ \\
\hline C-erbBZ & Positif & $8(16 \%)$ & $16(31 \%)$ & $\mathrm{p}<0,111$ \\
\hline
\end{tabular}

keganasan histopatologik KKA kelenjar liur sangat beragam, namun pada prinsipnya penggolongannya berdasarkan ada atau tidaknya tipe solid.9.11 Dalam penelitian ini semua kasus jaringan tumor KKA secara histopatologik memperlihatkan campuran kombinasi ketiga tipe pola pertumbuhan KKA sehingga kriteria derajat 1,2 , dan 3 pada penelitian ini merupakan modifikasi menurut Szantos dkk. ${ }^{10}$ dan Batsakis dkk. ${ }^{11}$ karena disesuaikan dengan kasus yang didapat; walaupun demikian persentase tipe solid merupakan keadaan yang menentukan tingginya derajat keganasan.

Beberapa peneliti menyatakan imunoekspresi E-cadherin pada jaringan kelenjar liur normal memperlihatkan ekspresi yang kuat dan stabil. Ekspresi kompleks E-cadherin-catenin juga telah diteliti pada kelenjar liur normal. Zhang dkk. ${ }^{12}$ menyatakan bahwa pulasan positif kuat kompleks E-cadherin-catenin terlihat pada sel kelenjar liur normal, sementara penurunan ekspresi kompleks telihat pada semua kasus KKA dan tingkat ekspresi kompleks E-cadherin-catenin positif berhubungan dengan diferensiasi sel tumor KKA. Imunoekspresi E-cadherin pada tumor jinak ternyata ekspresi positif E-cadherin pada membran sel sama seperti pada kelenjar liur normal. ${ }^{12}$ Lokasi ultrastruktur $E$-cadherin/ $\sigma$-/ $\beta$-catenin pada KKA dibandingkan dengan jaringan normal kelenjar labial, dinyatakan bahwa distribusi E-cadherin tidak selalu seragam dengan $\sigma$-/ $\beta$-catenin. Hal tersebut menunjukkan bahwa ekspresi E-cadherin yang tidak berikatan dengan catenin tidak berfungsi sempurna, sehingga fungsi adhesinya lemah atau tidak ada. ${ }^{13}$

Pada penelitian ini dasar pengelompokan derajat keganasan secara histopatologis berdasarkan persentase tipe solid pada jaringan tumornya, derajat 3 berupa jaringan KKA dengan tipe solid lebih dari 30\%. Dari 51 kasus jaringan KKA kelenjar liur mayoritas ekspresi E-cadherin negatif $(82 \%)$ dan terbanyak pada derajat 3 sebanyak $45 \%$ ( 23 kasus), sedangkan derajat 1 hanya 4\% (2 kasus). Kebermaknaan hubungan antara imunoekspresi E-cadherin dan derajat keganasan histopatologik KKA kelenjar liur juga sangat kuat $\left(\mathrm{Z}_{\mathrm{M}-\mathrm{W}}=3,364\right.$; $\mathrm{p}<0,001)$, yaitu intensitas negatif mengarah ke derajat 3 dan makin rendah distribusi pulasannya, makin tinggi derajat keganasan histopatologiknya. Dengan menggunakan analisis regresi logistik ganda hasilnya menunjukkan bahwa E-cadherin sangat kuat berhubungan dengan tingkat keganasan histopatologik $(\mathrm{p}=0,002)$. Semakin tinggi skor imunoekspresi E-cadherin, maka risiko terjadinya keganasan semakin rendah $(\mathrm{OR}<0,001)$. Hal ini menunjukkan bahwa rendah atau tidak terdapat ekspresi E-cadherin pada KKA kelenjar liur berhubungan sangat erat dengan tingginya derajat keganasan histopatologik. Oleh karena itu, seperti juga pada KKA kelenjar payudara, imunoekspresi E-cadherin pada KKA kelenjar liur dapat dipakai sebagai petanda keganasan. Demikian pula halnya dengan kriteria derajat keganasan histopatologik berdasarkan tipe pola pertumbuhan yang digunakan 
pada penelitian sesuai dengan keadaan progresivitas keganasan KKA kelenjar liur.

Produk onkogen dapat terlibat dalam regulasi gen E-cadherin pada tingkat transkripsional, di antaranya C-erbB2/HER2. Produk onkogen $C$-erbB2 diperkirakan mampu untuk menginduksi pengurangan ekspresi gen E-cadherin dan hal ini telah dipostulasikan menjadi hal yang penting dalam kanker mammae, namun sebaliknya pada penelitian Hellmann dkk. ${ }^{14}$ dinyatakan bahwa tidak terdapat hubungan ekspresi $E$-cadherin pada karsinoma duktal invasif payudara dengan status C-erbB2 (HER2/neu), derajat histologik, dan ukuran tumor. Mengenai imunoekspresi $C$-erbB2 pada KKA kelenjar liur masih kontroversial. Beberapa penelitian terdahulu membuktikan ekspresi $C$-erbB2 dari mulai $0 \%,<50 \%$, dan 50-100\%. ${ }^{9}$ Dalam penilaian lokasi ekspresi $C$-erbB2 kelenjar liur pada berbagai penelitian pun sangat bervariasi, yaitu penilaian hanya pada membran atau membran dan sitoplasma sel.,6 Rosa dkk. ${ }^{15}$ tidak dapat menemukan pulasan $C$-erbB2 pada membran sel pada semua kasus KKA kelenjar liur, hanya pada sitoplasma sel. Penilaian ekspresi $C$-erbB2 pada membran saja dan atau sitoplasma pada KKA sulit karena selnya tampak kecil dan padat dengan inti yang relatif besar dibandingkan dengan sitoplasma, sehingga penilaian ekspresi dalam penelitian ini berdasarkan sel tumor terwarna negatif $(<10 \%)$ dan positif $(\geq$ $10 \%$ ). Pulasan positifnya pada sitoplasma dan membran sel. Imunoekspresi $C$-erbB2 dengan derajat histopatologik mempunyai hubungan bermakna $\left(\mathrm{Z}_{\mathrm{M}-\mathrm{W}}=2,131 ; \mathrm{p}=0,033\right) \quad($ Tabel 2), walaupun kebermaknaan ini tidak berkorelasi dengan tingginya tingkatan keganasan. Ekspresi negatif $C$-erbB2 sedikit lebih banyak yaitu 53\% dibandingkan dengan yang positif (47\%) (Tabel 2), sedangkan hubungan antara ekspresi $C$-erbB2 dan derajat keganasan histopatologik, yang positif terbanyak pada derajat 2 (11 dari 24 kasus) dan yang negatif terbanyak pada derajat 3 (15 dari 27 kasus). Hal ini mendukung penelitian Dori dkk. ${ }^{9}$ yang menyatakan bahwa 50\% lebih kasus KKA, C-erbB2 diekspresikan sangat kuat pada tipe campuran tubular dan kribiform tetapi pada tipe solid ekspresinya lemah. Ekspresi kuat terbanyak di daerah invasif yaitu di dekat lokasi jaringan normal. Diduga bahwa peran $C$-erbB2 pada KKA dalam fungsi diferensiasi. ${ }^{9}$ Seperti diketahui, terdapat empat anggota keluarga $C-e r b B$, yaitu reseptor faktor pertumbuhan epidermal (EGFR/ erbB-1), C-erbB2/HER2/neu, C-erbB-3/HER3, dan C-erbB-4/Her4. Dalam keadaan normal terjadinya ikatan ligan faktor pertumbuhan yang spesifik dengan reseptornya menyebabkan agregasi reseptor sehingga terbentuk dimerisasi (homo atau heterodimer) dan diakhiri dengan internalisasi. ${ }^{16}$
Pembentukan dimerisasi ini akan menyebabkan aktivasi domein tirosin kinase reseptor instrinsik. Proses fosforilase serta defosforilase protein masing-masing dikatalisasi oleh protein kinase dan protein fosfatase. Hal tersebut merupakan kejadian biokimia yang mendasar untuk terjadinya transduksi sinyal intraselular sehingga transduksi sinyal tersebut tidak persisten. ${ }^{77,18} C$-erbB-2 mempunyai kekuatan aktivitas tirosin kinase tetapi tidak dapat mengikat setiap ligan yang dikenalnya, sebaliknya $C$-erbB-3 mengikat liganligan peptida, tetapi tidak mempunyai domein tirosin kinase. Walaupun demikian, C-erbB2 dan 3 dapat melakukan transduksi signal melalui pembentukan heterodimer dengan reseptor ErbB lainnya. $C-e r b B-2$ sepertinya lebih menyukai berpasangan pada proses dimerisasi dengan semua ErbB reseptor, namun heterodimer yang paling sering terbentuk yaitu $C$-erbB2 dengan $C$-erbB3. $C$-erbB2 dan 3 saling melengkapi kekurangannya sehingga dapat membentuk kompleks signal ErbB yang sangat kuat untuk proliferasi dan transformasi sel. Walaupun demikian, perbedaan kemampuan untuk membentuk heterodimer juga ditentukan oleh tingkat ekspresi reseptor $C$-erbB2. Diduga spontanitas dimersasi $C$-erbB2 pada sel tumor dapat terjadi pada reseptor yang tingkat ekspresi tinggi. ${ }^{19,20}$ Pada penelitian ini proses dimerisasi terjadi saat $C$-erbB2 terekspresi tinggi yaitu pada derajat histopatologik 2 , sedangkan pada derajat histopatologik tinggi (3) ekspresi $C$-erbB2 semakin menurun bahkan mayoritas negatif sehingga proses dimerisasi tidak terjadi. Hal tersebut dapat menjelaskan hasil penelitian ini, yaitu imunoekspresi $C$-erbB 2 dengan derajat histopatologik mempunyai hubungan yang bermakna namun bertambahnya ekspresi $C$-erbB2 ini tidak berkorelasi dengan semakin tingginya derajat keganasan. Dalam proses karsinogenesis proliferasi sel merupakan proses epigenetik berupa stimulus mitogenik memicu jalur transduksi sinyal untuk memblok fungsi gap junction sehingga sinyal pengontrol proliferasi terhambat, sedangkan proses proliferasi pada sel tumor berlangsung dengan sendirinya tanpa harus terjadi ikatan antara ligan spesifik dan reseptornya karena sel tumor mempunyai kemampuan untuk memproduksi faktor pertumbuhan peptid yang tinggi dan atau reseptornya. Fase promosi pada kasinogenesis merupakan proses mitogenik yang menyebabkan ekspansi klonal pada sel yang terinisiasi (sel yang tidak berdiferensiasi pada fase inisiasi) dan fase promosi pada karsionogenesis masih bersifat reversibel. Seperti telah dikemukakan sebelumnya bahwa tipe pola pertumbuhan tubular merupakan tipe dengan sel tumor yang masih berdiferensiasi baik bila dibandingkan dengan sel pada tipe kribiform yang kurang berdiferensiasi baik, namun 
tipe solid berdiferensiasi sangat buruk. Hubungan ekspresi positif dan negatif $C$-erbB2 dengan derajat keganasan histopatologik terlihat bahwa $C$-erbB2 yang positif terbanyak pada derajat 1 ada 5 kasus, derajat 2 ada 11 kasus, dan derajat 3 kembali menurun yaitu 8 kasus, sedangkan yang negatif pada derajat 1 tidak ada dan yang terbanyak pada derajat 3 ada 15 kasus. Berdasarkan hal tersebut penulis dapat menyatakan hal ini sangat berkaitan dengan sifat biologis KKA kelenjar liur yang tumbuh lambat namun progresif sehingga penderita mengalami prognosis yang buruk dalam jangka waktu yang lama. Selain itu, berdasarkan hasil yang didapat dapat dikatakan peran $C$-erbB2 pada KKA kelenjar liur terutama dalam fase inisiasi dan promosi.

Simpulan, imunoekspresi E-cadherin dapat digunakansebagaipetandatumoruntukmemprediksi prognosis keganasan KKA kelenjar liur. Perubahan imunoekspresi $C$-erbB2 pada KKA kelenjar liur menunjukkan perilaku biologinya dan peran utama $C$-erb $B 2$ pada KKA kelenjar liur terutama pada fase inisiasi dan promosi karsinogenesis.

\section{Daftar Pustaka}

1. Ellis FH, Gery L. Tumors of the salivary gland. Dalam: Hartman WH, Sobin LH, penyunting. Atlas of tumour pathology. Edisi ke-4. Portland Maine USA: Maine Medical Center; 2008. hlm. 229-40.

2. Cheuk W, Chan JKC. Advances in salivary gland pathology. Histopathology. 2007;51: 1-20.

3. Bradley PJ. Adenoid cystic carcinoma of head and neck: a review. Curr Opin Otolaryngol Head Neck Surg. 2004;12:127-32.

4. Gumbiner M. Regulation of cadherin adhesive activity [diunduh 22 Juni 2005]. Tersedia dari: http://www.jcb.org.

5. Steeg PS. Tumor metasatasis: mechanistic insights and clinical challenges. Nature Med. $2006 ; 12: 8-15$.

6. Ramis-Conde I, Drasdo D, Anderson AR, Chaplain MA. Modeling the influence of the E-cadherin-beta-catenin pathway in cancer cell invasion: a multiscale approach. Biophys J. 2008;95(1):155-65.

7. Lahlou H, Sanguin-Gendreau V, Zuo D, Cardiff RD, McLean GW, Frame MC, dkk. Mammary epithelial-specific disruption of the focal adhesion kinase blocks mammary tumor progression. Proc Natl Acad Sci. 2007; 104:20302-7.

8. Bankalvi A, Krabort M, Vegh A, Fetszeghy E, Piffko J. Deranged, expression of the E-cadherin/ $\beta$-catenin complex and the epidermal growth factor receptor in the clinical evolution and progression of oral squamous cell carsinomas. J Oral Pathol Med. 2002; 31:450-7.

9. Dori S, Vered M, Buchner A. HER2/neu expression in adenoid cystic carcinoma of salivary gland origin: an immunohistochemical study. J Oral Pathol. 2002;31:463-7.

10. Szantos PA, Luna MA, Tortoledo E, White RA. Histology grading of adenoid cystic carcinoma of the salivary glands. Cancer. 1984;54:10629.

11. Batsakis JG, Luna MA, Naggar AL. Histopathologic grading of salivary gland neoplasms: III adenoid cystic carcinoma. Ann Otol Rhinol Laryngol. 1990;99:1007-9.

12. Zhang ZY, Wu YQ, Zang WG, Tian Z, Cao J. The expression of E- cadherin-catenin complex in adenoid cystic carcinoma of salivary glands. Chin J Dent Res. 2003;3(3):36-9.

13. Shibuya Y, Ri S, Umeda M, Yoshikawa $\mathrm{T}$, Masago $\mathrm{H}$, Komori $\mathrm{T}$. Ultrastructural localization of E-cadherin and $\alpha$-/ $\beta$-catenin in adenoid cystic carcinoma. Histopathology. 2003;35(5):423-31.

14. Hellmann R, Lan F, McBride R, Helmann S. Separating favorable from unfavorable prognostic petandain breast cancer: the role of E-cadherin [diunduh 14 November 2004]. Tersedia dari: http://www.heimann@rover. uchiago.edu.

15. Rosa JC, Felix A, Fonseca I, Soares J. Immunoexpression of C-erbB2 and P53 in benign and malignant salivary neoplasms with myoepithelial differentiation. J Clin Pathol. 1997;50(8):661-3.

16. Guix M, Faber AC, Wang SE, Olivares MG, Song $\mathrm{Y}, \mathrm{Qu} \mathrm{S}$, dkk. Acquired resistance to EGFR tyrosine kinase inhibitors in cancer cells is mediated by loss of IGF-binding proteins. $\mathrm{J}$ Clin Invest. 2008;118:2609-19.

17. Andrechek ER, White D, Muller WJ. Targeted disruption of ErbB2/Neu in the mammary epithelium results in impaired ductal outgrowth. Oncogene. 2005;24:932-7.

18. Bazley LA, Gullick WJ. The epidermal growth receptor family. Endocrine-related Cancer. 2005;12:S17-27.

19. Lee-Hoeflich ST, Crocker L, Yao E. A central role for HER3 in HER2-amplified breast cancer: implications for targeted therapy. Cancer Res. 2008;68:5878-87.

20. Wansbury O, Panchal H, James M, Parry S, Ashworth A, Howard B. Dynamic expression of Erbb pathway members during early mammary gland morphogenesis. J Invest Dermatol. 2008;128:1009-12. 